\title{
Estimation of Private Locomotives Usage Efficiency for Freight Transportation in Ukraine
}

\author{
Dmytro Kozachenko ${ }^{1, *}$, Bogdan Gera ${ }^{2}$, Nazar Sannytskyy ${ }^{3}$, Yuliia Hermaniuk $^{2}$, and Tetyana Shargun $^{2}$ \\ ${ }^{1}$ Dnipro National University of Railway Transport, Department of Operation, 41010 Dnipro, Ukraine \\ ${ }^{2}$ Liviv Branch of Dnipro National University of Railway Transport, 79052 Lviv, Ukraine \\ ${ }^{3}$ Lviv College of Transport Infrastructure of Dnipro National University of Railway Transport, 79011 Lviv, Ukraine
}

\begin{abstract}
Ukraine has undertaken the implementation of European Union Directives, which provide nondiscriminatory admission to the railway infrastructure of independent carriers. A significant number of factors considerably affect working conditions of the carriers which are independent of Ukrzaliznytsia. One of the goals while performing transportation by independent carriers is the organization of private locomotives operation and their service by engine crews. The purpose of the article is to assess technical and economic indices of private locomotives use for goods transportation. The schemes of infrastructure objects arrangement for locomotives operation and engine crews work are presented. Performed calculations show the potential possibility of independent railway carriers to fulfil transportation to seaports with the use of its private locomotive infrastructure exclusively. The estimation of economically expedient volumes of cargo transportation by private locomotives in comparison with existing pricing of Ukrzaliznytsia is carried out. The nonlinear dependence of transportation volume depending on the distance is determined, at which the total cost of cargo transportation by Ukrzaliznytsia locomotives is equal to the cost of cargo transportation by private locomotives. The results of the study allow concerned companies to evaluate the investment efficiency into the development of locomotive fleet for rail transportation.
\end{abstract}

\section{Introduction}

Rail transport is the basis of the transport system of Ukraine and its share accounted $80 \%$ of cargo turnover (excluding pipeline transport) in 2018. At the same time, there was a negative trend in redistribution of freight volumes between railway and road transport in favor of the latter in recent years. This leads to the increase of expenditures for petroleum products for transportation and to deterioration of the country's energy balance. One of the main problems of modern railway transport in Ukraine that threatens both stability and safety of the industry is the crucial wear of its main means, locomotive fleet, in particular. Today, the electric locomotives deterioration is $93.0 \%$, and the diesel locomotives wear is $99.8 \%$. The reduction of rolling stock fleet leads to the reduction of transportation volume due to inability to master them, and to deterioration of infrastructure and car use and, consequently, to the loss of railway competitiveness and transition of freight traffic to competitive means of transport. Fig. 1 shows the dynamics of the number of Ukrzaliznytsia locomotives and the turnover of freight cars in relation to the indices of 2006, and Fig. 2 shows a field of points, which characterizes the relationship between these indicators. The analysis shows that between them there is a very strong inverse relationship with correlation coefficient -0.94 . Therefore, the locomotive fleet deficiency leads to the decrease of investors' interest in railcar fleet upgrading.

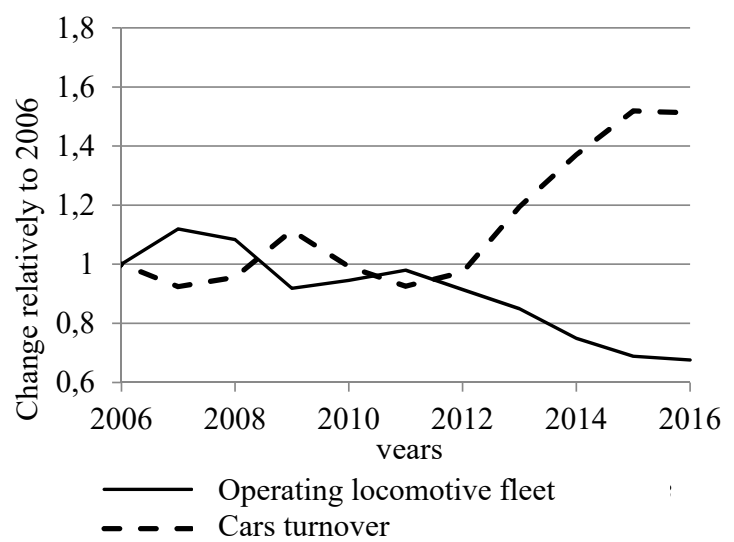

Fig. 1. Dynamics of operating locomotive fleet and cars turnover

Under these conditions, the issue of renewal of rolling stock fleet is topical and of crucial importance for the railway transport of Ukraine. It should be noted that in Ukraine there were attempts to renew the locomotive fleet massively. In particular, in the period from 2012 to 2016, the "Program of locomotive fleet updating for the railways of Ukraine" was functioning. The given 
program envisaged the purchase of 509 locomotives for 28.7 billion UAH, but it was not implemented. At present, according to the current program "Strategy of the Development of JSC "Ukrzaliznytsya"” acting until 2021 , the state monopolist plans to buy only 120 freight locomotives. In fact, until February 2019, Ukrzaliznytsya received only 22 locomotives Evolution TE33A produced by General Electric on terms of financial leasing.

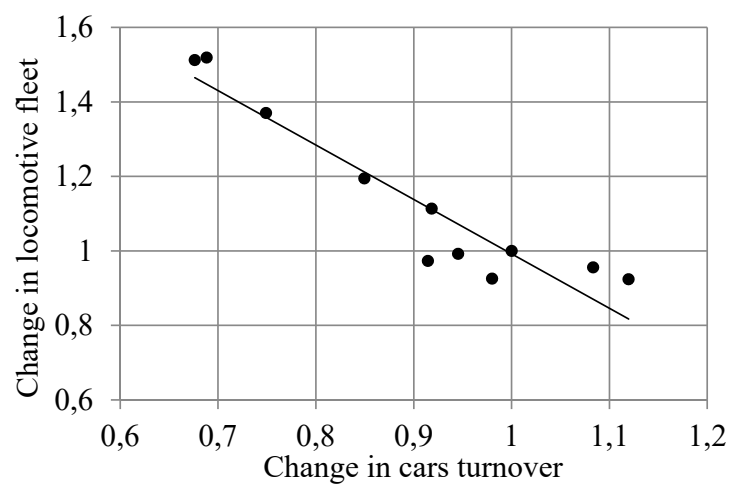

Fig. 2. Field of points that characterizes the correlation between locomotive fleet and cars turnover

In some cases, domestic enterprises carry out transportation of their cargoes by running between Ukrzaliznytsia stations using main locomotives. As an example, transportation of PJSC "Volyn-Cement" is executed between stations Kryvyn and Zdolbuniv (38 $\mathrm{km})$, SE "Chervonogradvantazhtrans" carries out transportation between stations Chervonograd, Girnyk and Sosnivka (6-14 km), PJSC "Ukrgrafit" performs transportation between station named after Anatoliy Alimov and Zaporozhye Live $(10 \mathrm{~km})$. Particular attention deserves the work of PJSC "Ivano-Frankivsk Cement", which fleet of main locomotives includes a new locomotive TE33A, three locomotives 2M62 and one locomotive M62, which transports raw materials on the routes Dubivtsi-Yamnitsa $(15 \mathrm{~km})$ and YamnitsaKhodorov $(70 \mathrm{~km})$. The economic efficiency of locomotives in ownership of industrial enterprises which are used on short sections of the track is mainly due to possibility of significant reduction of irregularity in transportation, rolling stock productivity increase and reduction of freight mass on wheels. For instance, at the section of the track Dubivtsi-Yamnitsa, the locomotive of PJSC "Ivano-Frankivsk Cement" performs up to 4 turnovers per day when the normative term of cargoes delivery by Ukrzaliznytsya on the same track section is 2 days. However, all these transportations are carried out on low-activity lines and are experimental.

Crisis phenomena at railway markets, which are in a monopoly state, are typical for many countries. In the European Union, as a solution to this problem, the vertical division of the railway industry is realized by separating infrastructure of the railway transport from transportation activities. At the same time, four packages of Directives of the European Union were issued. One of the main objectives of these Directives is to ensure nondiscriminatory access of independent carriers to railway infrastructure [1-3]. Studies of problems encountered by independent carriers are carried out in [4]. In particular, [4] studied the conditions of operation of the railways of Finland. As the main problems, railway carriers of Finland indicate the need for significant investments in rolling stock, discrimination at the stage of drawing up the timetable of trains traffic, the complexity of bureaucratic procedures while licensing. As for the conditions of Poland and Sweden, according to [5], the main barriers for entering the market are high cost of rolling stock traction and bureaucracy. To reduce the initial investment in locomotives, carriers prefer to exploit used locomotives. In [6], the analysis of the conditions for independent carriers' operation in Germany is presented, where the model of partial vertical division of the railway industry is implemented, when the infrastructure manager also has units that provide services for transportation of goods and passengers. It is noted that within the framework of regulatory norms in force in Germany, the infrastructure manager has the opportunity to create preferences for dependent on him carriers by varying the composition and quality of services access to the railway infrastructure. According to [7], the additional problems faced by independent carriers in Germany are that railway infrastructure in the country is primarily adapted for passenger transportation by DeutscheBahn group, so freight carriers are subject to increased technical standards; additional problems are created by the lack of full access to the information that characterizes infrastructure, etc.

In the Russian Federation, in accordance with the Federal Law "On Rail Transport in the Russian Federation" and the Federal Law "The Charter of Railway Transport of the Russian Federation", the access of carriers of different ownership to the main railway infrastructure is declared. However, since 2003, when these laws were passed, independent of Russian Railways carriers of goods have not appeared on the railways. At the same time, since 2003, private (rented) locomotives have been operating in the Russian Federation [8]. At the same time JSC Russian Railways remains the carrier. All private locomotives are mainly diesel locomotives and are owned by "Globaltrans", "Transgarant" and "Transoil". It is rather illustrative how private locomotives of OJSC "BaltTransServis" are exploited, which is part of the holding "Globaltrans". The main transportation by trains with private locomotives of OJSC "BaltTransServis" is carried out at Kuibyshev, North, South-Eastern, Moscow, Oktyabrskaya, Kaliningrad and North-Caucasian railways. The company "BaltTransServis" manages 60 main locomotives, but does not have its private depot or personnel of locomotive crews. Locomotives of the "BaltTransServis" fleet are used on closed routes, agreed with JSC Russian Railways. The shoulders of the locomotive turnover make up more than $1000 \mathrm{~km}$, while locomotives are operated by Russian Railways crews, and their servicing is carried out in the locomotive depots of Russian Railways. Under these conditions OJSC "BaltTransServis" acts in relation to JSC Russian Railways as a locomotive traction operator. 
At present, the fleet of private main-line locomotives makes up about $1 \%$ of main locomotives of the Russian Federation and accounts for about 3\% of freight transportation. One of the main reasons for limiting the admission of private locomotives to the main railway network in the Russian Federation is the imperfection of internal regulations of JSC Russian Railways. The absence of real steps from the side of Russian Railways to change these documents gives the opportunity to hold the market of freight transportation on railways in the monopoly condition.

Thus, the main problems limiting the use of private locomotive traction in vertical segmentation of market models is the high cost of access to the market, high cost of rolling stock traction, as well as imperfection of legislative and regulatory framework, which is designed to maintain competitive modes in the market.

Ukraine, on the one hand, and the European Union, the European Atomic Energy Community and their member states, on the other hand, signed the Association Agreement, under which Ukraine undertook implementation of the norms of the European Union in its legislation, including the Directives of the European Union concerning organization of railway transportation market. Taking into account that one of the main principles of this market organization is the formation of a competitive sector in the field of railway transportation, Ukraine has external obligations to organize the admission of independent carriers to the main railway infrastructure. The specified factor creates external requirements for the admission of locomotives of independent carriers to the railway network. At the same time, the crucial wear of the locomotive fleet and the inability to develop scheduled volumes of transportation is an internal stimulus for introduction of private locomotive traction.

\section{Methodology}

The legislative and regulatory framework of Ukraine in force does not exclude operation of locomotives that do not belong to Ukrzaliznytsia on the main railway network. The activity of such locomotives on public railways is governed by clause 9.12 of the Rules of Technical Operation of the Railways of Ukraine. At the same time, "The collection of tariffs for freight transportation within Ukraine and related services" includes clause 20, according to which tariffing of cargo transportation on railways of general use by trains with private (rented) locomotives is carried out. In this case, payment for loaded or empty cars is determined according to tariff plans 29.1-29.4 for locomotives and cars separately. Running of private or rented locomotives "under its own power" on the general network of railways of Ukraine (except those associated with transferable operations) is paid by tariff plans 29.5 or 29.6 .

Taking into account considerable length of legislative and regulatory framework development for creation of non-discriminatory conditions of independent carriers' access to the main railway infrastructure, it is important to determine the area of private locomotives effective use to ensure freight transportation on railways under current regulatory framework and tariffs.

When performing transportation by independent companies there is mutual financial responsibility between an owner and an infrastructure manager for infrastructure provision and its use as

- delays of trains of independent carriers caused by an infrastructure manager or other carriers' fault, may cause the breach in timing of their locomotive crews and significant secondary delays and unscheduled expenses due to the need for their delivery to rotation stations;

- delays of trains of independent carriers caused by an infrastructure manager or other carriers' fault may cause the breach in operation conditions of the companies they serve;

- delays of trains of independent carriers caused by their fault can provoke train delays of other carriers.

Under such conditions, the problem of ensuring the access of rolling stock to the main and receiving-entry tracks and elimination of conflict situations with train and shunting movements of rolling stock of Ukrzaliznytsya is solved by passing trains of independent carriers in accordance with the rigid schedule [8-11]. The organization of independent carriers' locomotives access to the locomotive infrastructure when transportation is carried out without compliance with freight trains schedule is a problematic issue connected with provision of a non-discriminatory access and the lack of tariffs for such services. Moreover, delays in locomotives maintenance will also cause trains demurrage on the main infrastructure; the tariffs for its use is also absent. In this regard, at the stage of transport market formation, the scheme will be effective, if locomotive service centers are located at points, where loading or unloading of train blocks are concentrated [12].

Performed research shows that diesel locomotives used on Ukrzaliznytsia can serve routes of up to $822 \mathrm{~km}$, and electric locomotives can serve routes of up to 1000 $\mathrm{km}$ under condition of locomotive infrastructure concentration for performance of equipment and maintenance of locomotives at points of loading or unloading. Possible schemes for organization of private diesel locomotives and their locomotive crews' operation are given in Fig. 3.

General expenditures for transportation of 1 ton of cargo by Ukrzaliznytsia can be determined by the formula.

$$
E_{r}=\frac{e_{i l}(L, g)+e_{i e}(L)+\theta_{r}(L) e_{c}}{q}
$$

where $L$ - distance of transportation, $\mathrm{km} ; g$ - type of cargo; $e_{i l}(L, g), e_{i e}(L)$ - respectively, infrastructure services and locomotive traction of Ukrzaliznytsia costs during car transportation loaded with cargo $g$ and an empty car depending on the distance of transportation $L$, UAH; $\theta_{r}(L)$ - car turnover when transporting by Ukrzaliznytsia locomotives depending on the distance of transportation $L$, days; $q$ - load carrying capacity of the car, $t$. 


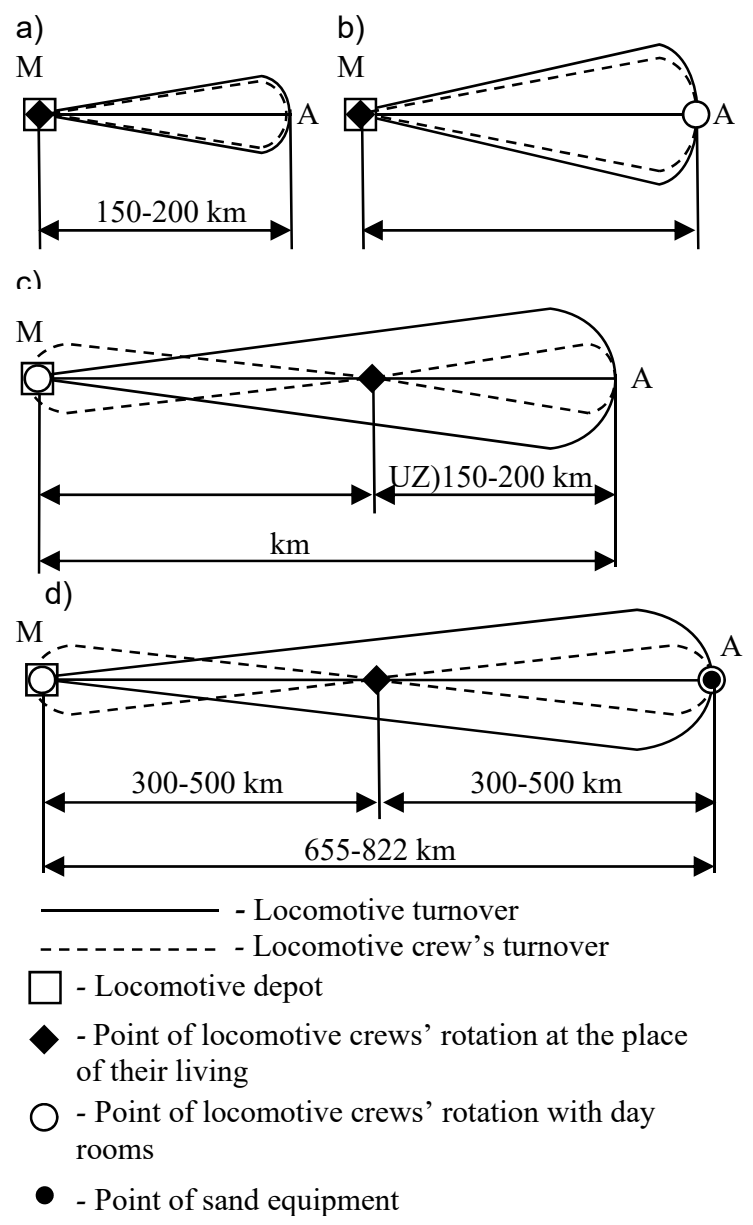

Fig. 3. Schemes of work organization of diesel locomotives and locomotive crews of independent carriers.

Total costs for cargo transportation by private (rented) locomotives can be determined by the formula.

$$
\begin{aligned}
& E_{p}=\frac{e_{p l}(L, g)+e_{p e}(L)+E_{f}(L)+E_{c r}(L)+E_{l}(L)}{q m}+ \\
& +\frac{e_{c l}(L, g)+e_{c e}(L)+\theta_{p}(L) e_{c}}{q}
\end{aligned}
$$

where $e_{p l}(L, g), e_{p e}(L)$ - respectively, the cost of Ukrzaliznytsia infrastructure services for accessing it with own (rented) locomotive during cars transportation with cargo $g$ and empty cars for distance $L$, UAH; $e_{c l}(L, g), e_{c e}(L)$ - respectively, the cost of infrastructure services of Ukrzaliznytsia for a car accessing it with load $g$ and an empty car during transportation in the train formation with its own (rented) locomotive for distance $L, \mathrm{UAH} ; E_{f}(L), E_{c r}(L), E_{l}(L)$ - respectively, the costs connected with fuel (electricity) payment, the work of locomotive crews, as well as the purchase and maintenance of a locomotive for one trip at the length $L$, $\mathrm{UAH} ; \mathrm{m}$ - number of cars in train formation; $e_{c l}(L, g), e_{c e}(L)$ - respectively, the cost of Ukrzaliznytsia infrastructure services for a car accessing it with cargo $g$ and an empty car in the train formation with own (rented) locomotive for distance $L$, UAH; $\theta_{p}(L)$ - car turnover during transportation in the train formation with its own (rented) locomotive, depending on the distance of transportation $L$, days.

\section{Results}

In the course of study, calculations were made of the costs connected with transportation for different distances of iron ore in gondolas (tariff scheme 1) and grain in grain cars (tariff scheme 2) by diesel locomotives and electric locomotives that are new and used. For example, Fig. 4 shows the distribution of costs connected with iron ore transportation for $500 \mathrm{~km}$.

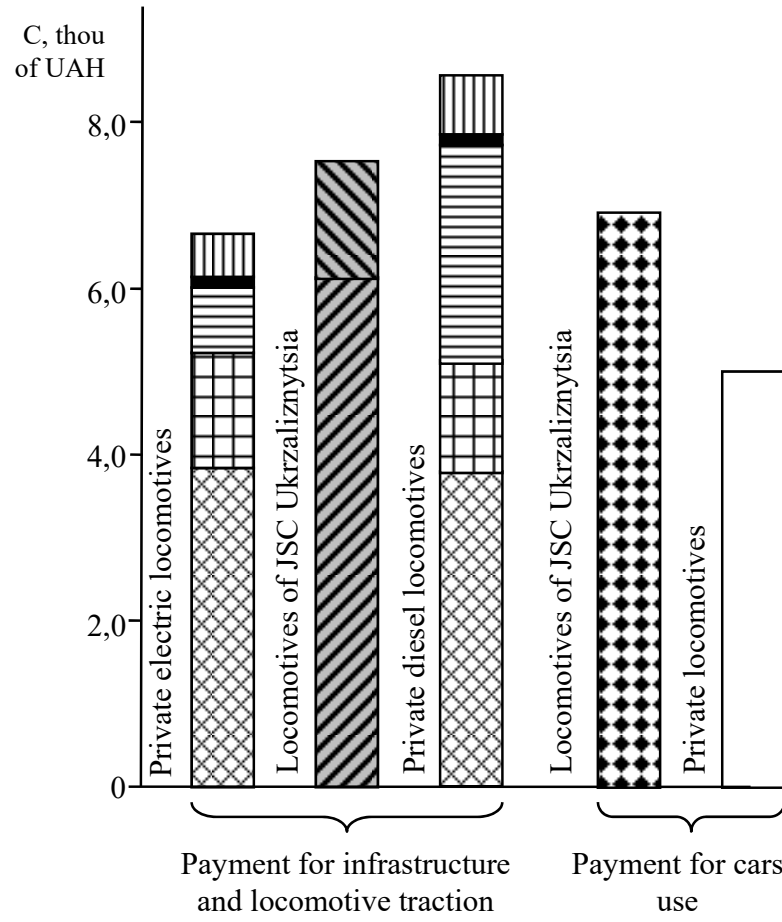

P - Payment for infrastructure (freight running, private locomotive) $300-500 \mathrm{~km}$

円] - Payment for infrastructure (empty running, private locomotive) $300-500 \mathrm{~km}$

- Payment for infrastructure and locomotive traction (freight running, locomotive

- Payment for infrastructure and locomotive traction (empty running, locomotive UZ)

El - Expenditures for fuel (electricity)500-65

- Expenditures for locomotive crews work

- Expenditures for locomotive purchase and exploitation

- Expenditures for car use (locomotive UZ) - Expenditures for car use (private
locomotive)

Fig. 4. Distribution of expenses for transportation of iron ore for distance of $500 \mathrm{~km}$ by locomotives of JSC Ukrzaliznytsya and own (rented) locomotives 
The analysis of Fig. 4 shows that the main effect of private traction implementation is achieved by increasing the efficiency of freight car use and reducing expenditures for its use. It should also be noted that Ukrzaliznytsia's revenues from provision of infrastructure for transportation by private diesel locomotives are close to Ukrzaliznytsia's revenues from transportation cargoes, excluding fuel costs and expenses for locomotive crews' labor costs.

Fig. 5, $a$ and $b$ represent the dependence of cost savings of consignors on the distance traveled by private locomotives.
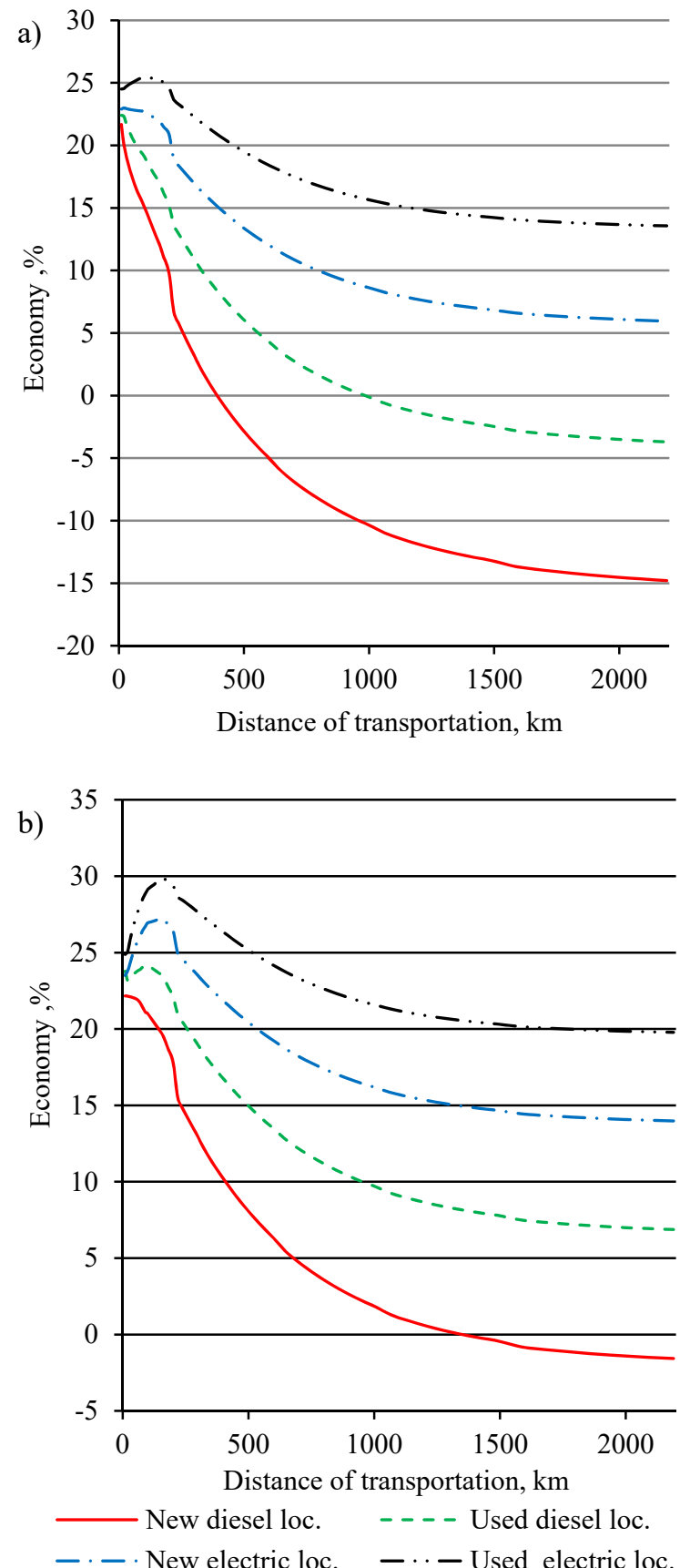

Fig. 5. Economy of private locomotives use during transportation of iron ore (a) and grain (b)

The maximum effect from implementation of private locomotive traction is achieved when transporting cargoes for distances up to $300 \mathrm{~km}$, where transportation can be carried out by one locomotive crew during the locomotive turnover, after which the effect is reduced. Exploitation of private electric locomotives and used diesel locomotives has an economic benefit for all distances that are possible in Ukraine. The use of new diesel locomotives is inefficient for transporting iron ore and coal for distances of more than $400 \mathrm{~km}$, and ineffective for grain transportation for distances of more than $1300 \mathrm{~km}$.

To ensure the recoupment of capital investments into the development of rolling stock fleet, independent transport companies should carry out relevant volumes of transportation. As a result of the research, nonlinear dependencies of transportation volumes from the distance are established, where total expenses for cargoes transportation by Ukrzaliznytsya locomotive are equal to the costs for cargoes transportation by own (rented) locomotive. The corresponding curves allow to determine areas within which the exploitation of private locomotive traction provides an economic effect. An example of such areas for iron ore and grain transportation is shown in Fig. 6.

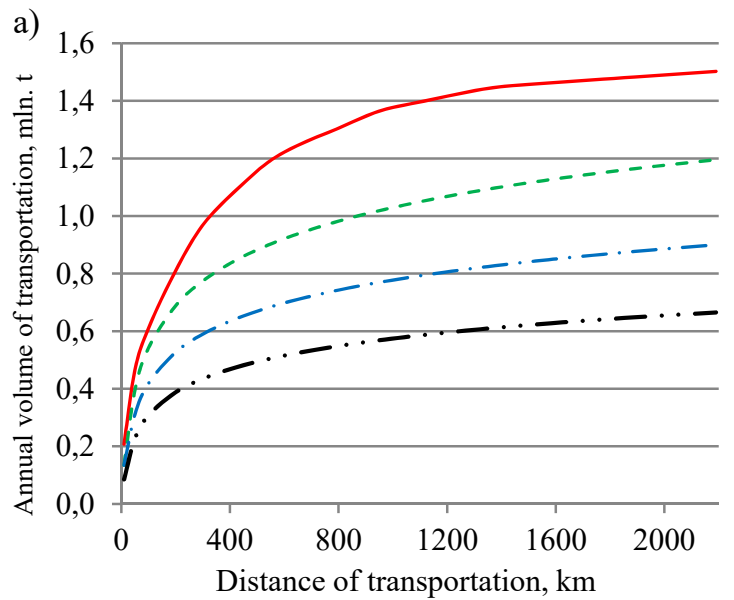

b)

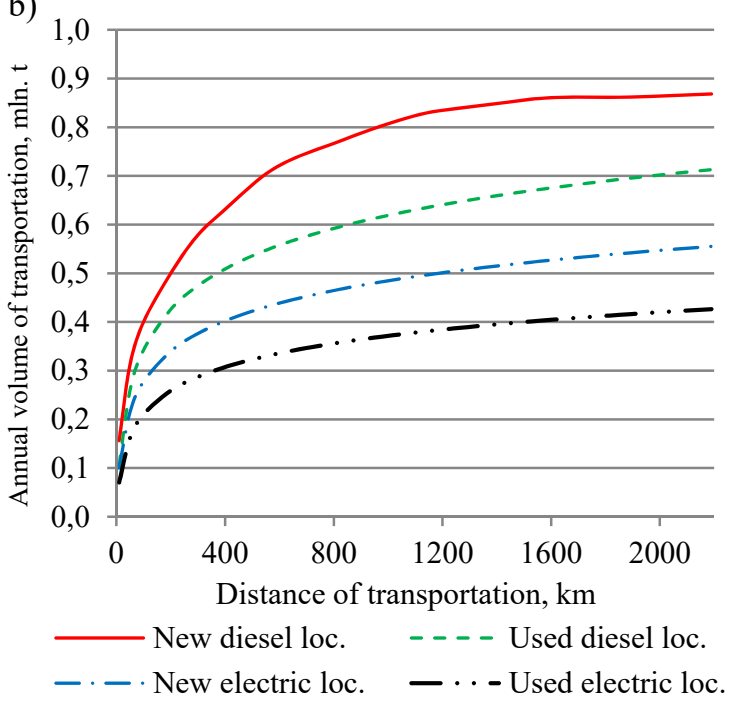

Fig. 6. Minimal volumes of transportation providing economic efficiency of private traction: a - iron ore; $\mathrm{b}$ - grain 


\section{Scientific novelty and practical significance of work}

As a result of the performed researches, for the first time, dependencies are established that determine the areas of efficient use of private locomotives for railway transportation within Ukraine.

\section{Conclusions}

The admission of private locomotives to the main railway network of Ukraine is one of the methods that allows solving the problem of rolling stock shortage. The given measure meets the obligations undertaken by Ukraine under the Association Agreement between it and the European Union, the European Atomic Energy Community and their member states.

\section{References}

1. R. Pittman, Options for Restructuring the StateOwned Monopoly, Railway Research in Transportation Economics, Vol. 20, 179-198 (2007). https://doi.org/10.1016/S0739-8859(07)20007-1

2. A. Laurino, F. Ramellab, P. Beria, The economic regulation of railway networks: A worldwide survey, Transportation Research Part A: Policy and Practice, Vol. 77, 202-212 (2015). doi: 10.1016/j.tra.2015.04.011

3. R. Pittman, Reforming and restructuring Ukrzaliznytsia: a crucial task for ukrainian reformers, Science and Transport Progress, No. 1 (67), 34-50 (2017). doi:10.15802/stp2017/92775

4. M. Makitalo, Market entry barriers in Finland's rail freight transport, World Review of Intermodal Transportation Research, Vol. 3, No. 1/2, 181-195 (2010). doi: 10.1504/WRITR.2010.031587
5. M. Laisi, M. Makitalo, O.-P. Hilmola, Stimulating competition in the liberalized railway freight market, Baltic Journal of Management, Vol. 7, No. 1, 68-85 (2012). doi 10.1108/17465261211195865

6. H. Link, Rail infrastructure charging and on-track competition in Germany, International Journal of Transport Management. Vol. 2., Iss. 1, 17-27 (2004). doi :10.1016/j.ijtm.2004.05.002

7. B. Slack, A. Vogt, Challenges confronting new traction providers of rail freight in Germany, Transport Policy, Vol. 14, No. 5, 399-409 (2007). doi:10.1016/j.tranpol.2007.04.003

8. D. Kozachenko, R. Vernigora, N. Berezovy, Perspectives of the Private Locomotives Use for Main Rail-freight Traffic in Ukraine, Ukrainian Railways, No. 1, 50-55 (2013). (In Russian)

9. D. Kozachenko, R. Vernigora, V. Balanov, N. Berezovy, L. Yelnikova, Y. Germanyuk, Evaluation of the transition to the organization of freight trains traffic by the schedule, Transport problems, Vol. 11, Iss. 1, P. 41-48 (2016). doi: 10.20858/tp.2016.11.1.4

10. D. Tsutskov, Selection of the optimal technological parameters of the organization of transportation process with solid thread chart, Proceedings VNIIAS, No. 3, 66-75 (2005). (In Russian)

11. N. Berezovy, Transportation of steel products circular route schedule with private locomotives, East European Journal of advanced technologies, No. 2(3), 51-55 (2014). (In Russian). DOI: https://doi.org/10.15587/17294061.2014.23089

12. D. Kozachenko, R. Vernigora, V. Balanov, N. Sannytskyy, N. Berezovy, T. Bolvanovska, Improving the Methods of Estimation of the Unit Train Effectiveness, Transport problems, Vol. 11, Iss. 3, 91-101 (2016). doi: 10.20858/tp.2016.11.3.9 